\title{
Melacak Teori Rasionalitas Ekonomi berbasis Islamic Ethics
}

\author{
Ali Amin Isfandiar \\ Jurusan Ekonomi Syariah STAIN Pekalongan \\ Email:alminist@yahoo.com.
}

\begin{abstract}
This paper discusses the rationality from the angle of language and its coverage, rationality from the standpoint of immanence and transcendence. The theme of the study are about the relationship between ethics and rationality, rationality in economics including the position of rationality in Islamic economy, the role of the outsider (external factors) of rationality (in economy in taking decisions). The approach used is a philosophicalexploratory, i.e. tracing the linguistic philosophical side which started from the rational root of the word itself is up to on the word transformation in economics, so that gave rise to some form of the word rational that was so extreme and radical as the pretext of self to behave as free-free economy. The presence of characteristic trandensi in Islamic economy which is not owned by the conventional economy, namely the risk of uncertainty as to the resigned expression tawwakul and unrestricted time jangkauang (time horizon) from the life of the world to the life of the hereafter.
\end{abstract}

Keywords: Rationality, ethics, Islamic economics

\begin{abstract}
Abstrak
Tulisan ini membahas rasionalitas dari sudut bahasa dan cakupannya, rasionalitas dari sudut pandang imanensi dan transendensi. Tema kajian adalah mengenai hubungan antara etika dan rasionalitas, rasionalitas dalam bidang ekonomi termasuk di dalamnya posisi rasionalitas dalam ekonomi Islam, peranan outsider (faktor eksternal) terhadap proses rasionalitas (ke dalam diri pelaku ekonomi dalam mengambil keputusan). Pendekatan yang digunakan adalah filosofis-eksploratif, yakni menelusuri sisi filosofis kebahasaan yang dimulai dari akar kata rasional itu sendiri hingga sampai pada proses transformasi kata tersebut dalam bidang ekonomi, sehingga memunculkan bentukan kata rasional yang begitu ekstrim dan radikal sebagai
\end{abstract}


dalih diri untuk berperilaku sebebas-bebasnya dalam bidang ekonomi. Adanya karakteristik trandensi dalam ekonomi Islam yang tidak dimiliki oleh ekonomi konvensional, yaitu pasrah kepada resiko ketidakpastian sebagai ekspresi tawakal dan jangkauang waktu yang tak terbatas (time horizon) dari kehidupan dunia sampai kehidupan akhirat.

Kata Kunci: Rasionalitas, etika, Ekonomi Islam

\section{Pendahuluan}

Manusia tertambat oleh hasratnya. Demikian Adam Smith menuturkan dalam The Theory of Moral Sentiment. Lebih lanjut, Smith (dalam Keraf, 1996: 56) menyatakan, bahwa manusia mempunyai hasrat kodrati yang membuat dirinya cenderung pada dua sisi yang berbeda, yaitu kodrat untuk mempertahankan hidupnya dan kodrat untuk peduli terhadap situasi dan kehidupan sesama. Penempatan diri sendiri (selfish) di atas segalanya untuk disejahterakan adalah prioritas kodrati yang tidak bisa ditawar, sedangkan proses pensejahteraan diri terikat dengan etika. Dan etika "kedirian" itu dipaksa harus memunculkan sensitivitas pada lingkungan sekitar karena secara kodrati pula ia terikat dengan psikologi sosial yang menuntut dirinya untuk menjadi makhluk sosial.

Sering dipahami self-interest bermakna maksimisasi kepuasan (konsumsi) dan keuntungan (produksi). Sementara banyak paradigma baru yang memaknai bahwa self-interest tidak selalu berarti memperbanyak kekayaan seseorang dalah satuan rupiah tertentu. Asumsi yang muncul adalah bahwa individu mengejar berbagai tujuan, bukan hanya memperbanyak kekayaan secara moneter. Ia ternyata juga mencakup berbagai tujuan yang berhubungan dengan prestise, persahabatan, cinta, kekuasaan menolong sesama, penciptaan karya seni, dan sebagainya. Ia juga memunculkan proyeksi keluar diri pelaku, di mana individu dalam rangka mencapai sesuatu yang membuat dirinya lebih baik, pada saat yang sama membuat orang di sekitarnya juga menjadi lebih baik (Karim, 2007: 52).

Kodrat manusia untuk peduli pada diri sendiri pada dasarnya sama dengan teori self-interest (keinginan pribadi) dalam ilmu ekonomi, di mana setiap individu maupun komunitas harus berusaha dan diberi kebebasan 
untuk memenuhi keinginan dan kebutuhannya sendiri untuk mempertahankan hidup (QS. Al-Baqarah (2): 195). Perilaku tersebut dikatakan sebagai bentuk perilaku rasional, yang aplikasinya dalam ilmu ekonomi merambah di semua aspek seperti produksi, distribusi, konsumsi, dan aspek yang lain. Misalnya saja dalam hal konsumsi, daya beli menjadi ukuran individu maupun komunitas untuk memenuhi kebutuhan dan keinginan. Pertimbangan matang dalam mengalokasikan dana (budget) yang akan dibelanjakan dan prioritas komoditas yang hendak dibeli menjadi top rank, agar terhindar dari akibat, yang dalam Islam disebut tabdzir (boros), meskipun dari sudut ekonomi, perilaku konsumsi dalam memenuhi kebutuhan tadi merupakan hak prerogratif konsumen dalam membelanjakan komoditas sesuai dengan alokasi dana yang dimiliki.

Dalam konteks tabdzir (boros) pun memunculkan masalah baru, yakni hilangnya rasa kepedulian sosial. Di satu pihak terjadi maximization of spending (maksimisasi belanja) dari budget yang dianggarkan atau bahkan melebihi, sementara di pihak lain terjadi minimization of spending (minimisasi belanja) atau bahkan defisit. Meskipun maksimisasi diperbolehkan, namun runtuhnya nilai-nilai kepedulian sosial menjadi harga mahal yang harus dibayar oleh manusia sebagai makhluk sosial. Persoalan ke depan adalah bagaimana model-model rasionalitas yang dikembangkan oleh Islam dapat memunculkan dimensi etis dan kepedulian sosial yang ditransformasikan dalam bentuk aksi nyata di bidang ekonomi tidak hanya mencakup aspek konsumsi tetapi juga aspek-aspek yang lain.

Makalah ini akan membahas beberapa sub topik sebagai batasan. Sub topik tersebut antara lain rasional dan rasionalitas dari sudut bahasa dan cakupannya, rasionalitas dari sudut pandang imanensi dan transendensi, hubungan antara etika dan rasionalitas, rasionalitas dalam bidang ekonomi termasuk di dalamnya posisi rasionalitas dalam ekonomi Islam, peranan outsider (faktor eksternal) terhadap proses rasionalitas (ke dalam diri pelaku ekonomi dalam mengambil keputusan).

Pendekatan yang digunakan dalam penulisan makalah ini adalah filosofis-eksploratif, yakni menelusuri sisi filosofis kebahasaan yang dimulai dari akar kata rasional itu sendiri hingga sampai pada proses transformasi kata tersebut dalam bidang ekonomi, sehingga memunculkan bentukan kata 
rasional yang begitu ekstrim dan radikal sebagai dalih diri untuk berperilaku sebebas-bebasnya dalam bidang ekonomi. Akhirnya, kekurangan dan kelemahan makalah ini pasti ada, oleh karena itu kritik untuk perbaikan makalah ini menjadi niscaya dan diharapkan.

\section{Rasionalitas: telaah semantik dan cakupan}

"Rasionalitas" mempunyai akar dan bentukan kata yang boleh jadi secara kebahasaan menunjukkan makna dan konotasi yang berbeda-beda, seperti ratio (latin)/ rasion (ration), rasional (rational), rasionalitas (rationality), dan rasionalisme (rationalism) (Raliby, 1982: 436; 934; Salim, 2000: 1212). Ratio (latin) berarti akal budi atau pikiran sehat. Rasion (ration) mengandung makna di antaranya to supply with the rations (menawarkan dengan ketentuan), to limit or to restrict the use of (membatasi penggunaan barang tertentu). Ration dalam bidang ekonomi mengerucut pada makna adanya batasan yang ditentukan oleh sebuah ketentuan.

Rasional (rational) adalah lawan dari irrational, secara bahasa diartikan seperti ungkapan rational human beings (manusia yang dapat berpikir), rational behaviour (perilaku yang masuk akal). Ia juga yang mengandung makna measureble in matrical units (dapat diukur dengan satuan angka), agreeable to reason (dapat disetujui dengan pertimbangan akal budi / alasan), pertaining to or acting in conformity to reason (bersinggungan atau bertindak sesuai dengan akal budi). Makna tersebut dapat diambil intinya bahwa rasional mengandung pengertian tentang keputusan dan tindakan yang didasari atas pertimbangan akal budi.

Rasionalitas (rationality) adalah istilah yang berkaitan dengan gagasan akal yang berkonotasi pada proses berpikir dalam memberikan laporan atau keterangan. Ia menyangkut dua aspek, yaitu (1). Aspek yang berkaitan dengan pemahaman, kecerdasan dan pengambilan keputusan, (2) kemasukakalan dari penjelasan, pemahaman atau pembenaran. Ia juga mengandung makna quality of being rational (kualitas menjadi rasional), possession of reason (mengandung alasan), reasonableness (layak), rational act or belief (tindakan atau keyakinan yang rasional). Makna terakhir menunjukkan bahwa rasionalitas mengarah pada dua dimensi, yaitu keyakinan dan tindakan yang menurut pelakunya sebagai rasional (dan 
rasional sendiri digerakkan oleh akal budi). Proses rasionalitas disebut dengan rationalization (rasionalisasi) yang mengandung makna to find motives for conduct which are plausible (pencarian motif tindakan yang masuk akal).

Rasionalisme (rationalism) mengandung makna development of opinions deduced from reason as distinct from inspiration or revelation (pengembangan pemikiran yang disimpulkan dari akal budi sebagai pembeda dari inspirasi -ilham- atau wahyu). Dalam bidang filsafat ia diartikan dengan teori yang mengatakan bahwa reason (akal budi) -bukan persepsi- adalah standar (ukuran) kebenaran dan sumber ilmu pengetahuan. Dalam bidang teologi, ia mengandung makna penerimaan akal sebagai sumber kebenaran agama dengan mengabaikan wahyu dan kekuatan supernatural (bersifat gaib).

Rasionalisme berseberangan dengan Empirisme (Sensasionalisme). Rasionalisme condong berpendapat bahwa kebenaran dapat dicapai dengan jalan berpikir dan menarik kesimpulan dengan akal dari hal yang sudah tentu yang diajukan lebih dulu. Sementara Empirisme menyatakan bahwa satusatunya sumber pengetahuan adalah kesadaran panca indera dan satu-satunya percobaan pengetahuan adalah pengalaman. John Lock menjelaskan sikap empirisme, Leibniz menguraikan sikap rasionalisme, sementara sebagai penengah muncul Immanuel Kant. Kant berusaha menyesuaikan sikap itu dengan memisahkan lapangan yang dapat dibicarakan dengan akal dan pengalaman dari lapangan yang masuk lingkungan kepercayaan. Hasilnya adalah Agnosticisme, suatu hasil yang juga terdapat pada aliran rasionalistik kuno, Stoicisme. Sikap pragmatis atau instrumentalis, yang menghindarkan soal itu dengan memberikan pembatasan baru tentang kebenaran.

Rasionalitas dan akal budi (pemikiran) adalah metode kunci yang digunakan untuk menganalisis data yang dalam suatu observasi yang sistematis. Di ilmu ekonomi, sosiologi dan ilmu politik, sebuah keputusan atau situasi sering disebut rasional, jika ditujukan untuk optimalisasi dalam mengejar tujuan. Pada konsep rasionalitas, tujuan atau motif individu yang diambil oleh pelaku itu mengabaikan kritik dan etika. Sederhananya rasionalitas merujuk pada kesuksesan meraih tujuan apapun. Rasionalitas identik dengan perilaku yang digerakkan oleh self-interest yang mengarah pada perilaku selfish (egois atau mementingkan diri sendiri). 
Terkadang rasionalitas juga diartikan memiliki informasi yang lengkap dan detail tentang situasi tertentu, karena tujuan tidak terlalu penting keterkaitannya dengan definisi rasionalitas yang hanya menuntut konsistensi logis dalam membuat pilihan. Oleh karena itu, rasionalitas merupakan prinsip sentral dalam artificial intelligence, di mana agen rasional secara khusus didefinsikan sebagai agen yang selalu memilih perilaku yang memaksimisasi apa yang diharapkan dan maksimisasi informasi yang dimiliki.

Mengenai kualitas rasionalitas, diakui para ahli ilmu sosial bahwa rasionalitas yang baik harus bebas dari emosi, perasaan pribadi atau insting (naluri). Agen dikatakan irrasional bila terpengaruh oleh emosi pribadi, perasaan, insting, budaya tertentu, aturan moral dan norma. Namun hal tersebut terasa berat dan tidak mungkin dilakukan oleh kebanyakan manusia ketika berusaha mencari kepuasan. Bahkan kebanyakan persoalan dianalis dengan pemahaman yang berbasis budaya dan etika.

Berkenaan dengan teori rasionalitas, sosiolog Jerman, Max Weber, mengemukakan bahwa interpretasi perilaku sosial dibedakan menjadi 4 tipe rasionalitas. Pertama, Zweckrational or purposive/instrumental rationality, berhubungan dengan harapan tentang perilaku manusia atau objek sekitarnya. Ia menyebut dengan rationally pursued and calculated. Kedua, Wertrational or value/belief-oriented. Perilaku dipengaruhi oleh reasons intrinsic yang muncul dari etika, estetika, agama, dan motif yang independen. Ketiga, affectual. Rasionalitas yang ditentukan oleh pengaruh internal pelaku seperti perasaan atau emosi. Ia menyebutnya dengan meaningfully-oriented rationality. Keempat, traditional, ditentukan oleh ingrained habituation (kebiasaan yang melekat).

Keempat tipe tersebut, Weber menegaskan, akan terjadi secara kombinasi; dua tipe pertama yang paling menentukan, sedang dua setelahnya merupakan pengembangan dari dua yang pertama.

\section{Rasionalitas: antara imanensi dan transendensi}

Hal yang harus dirubah mengenai cara pandang mensikapi rasionalitas adalah munculnya transformasi ke arah transendensi yang seharusnya disadari oleh manusia secara keseluruhan, meskipun kelemahan terpenting adalah ia masih bersifat normatif, tinggal bagaimana formulasi itu membumi. 
Cara pandang tersebut:

1. Dari self-interest ke social-interest (religious altruism) / Social consideration

Manusia pribadi harus mengutamakan hidup dengan mementingkan diri sendiri. Hidup di sini tidak semata-mata hidup dari aku yang partikular (hidup yang menganggap sendiri dan terpisah dengan orang lain). Melainkan prinsip ini mengacu pada hidup dari aku yang universal, aku alam, atau singkatnya aku-nya siapa saja, atau lebih tepat, pribadi (self) dalam kepentingan pribadi (self-interest) harus dibaca sebagai entitas transendental-universal dan bukan sekedar pribadi dari aku atau dia yang partikular. Kepentingan diri tersebut merupakan prinsip conatus essendi, yang bertentangan dengan dengan conatus essendi-nya Thomas Hobbes yang cenderung mengejar kepentingannya sendiri bahkan dengan mengorbankan kepentingan orang lain sekalipun.

\section{Extended time horizon}

Dalam Islam, (1) waktu tidak dibatasi hanya pada masa kini, tetapi ia memandang sebagai horizon, (2) waktu sangat penting dan sangat bernilai. Nilai waktu tergantung pada bagaiamana seseorang memanfaatkan waktunya semakin produktif seseorang memanfaatkan waktunya, semakin banyak nilai yang diperolehnya. Bagi setiap orang, sehari adalah 24 jam, tetapi nilai waktunya akan berbeda-beda. Tentu saja, hal tersebut dapat diukur salah satunya dengan moneter, di mana setiap orang selalu akan berorientasi kepadanya (Karim, 2007: 59).

Dengan time horizon yang lebih panjang ini, maka seorang agen ekonomi akan merasakan ketidakpastian, terutama yang menyangkut maslahah. Ia menghadapi situasi ketidakpastian mengenai apakah maslahah yang akan diperolehnya di akhirat lebih baik atau lebih buruk dari yang dirasakan di dunia. Menurut aksioma quasi-concavit, agen muslim dipastikan akan melakukan harmonisasi maslahah yang diterima di dunia dan diakhirat. Quasi-Concavity semakna non-decreasing process, artinya target atau pencapaian hidup yang selalu meningkat dan terbaik, sesuai dengan konsep dalam Islam tentang keberuntungan, yang menyatakan bahwa "barang siap yang esok lebih baik dari sekarang adalah orang yang beruntung". Cara yang dilakukan sebagaimana yang 
dijelaskan sebelumnya dengan mengorbankan kenikmatan dunia ini demi kenikmatan diakhirat (Direktorat Perbankan Syariah \& Pusat Pengkajian dan Pengembangan Ekonomi Islam, 2007: 19-21).

3. Islamic world-view on uncertainty

Dalam Islam, fenomena di dunia tidak ada yang pasti kecuali kematian, termasuk fenomena bidang apapun dalam ekonomi. Perencanaan yang matang, koordinasi yang sistematis, manajemen yang profesional tidak ada yang menjamin kepastian sebuah aktivitas yang berujung keputusan final. Efek dari time horizon membuat orang tergerak untuk lebih arif bahwa ada kekuatan transendental yang bisa merubah segala. Bahwa human proposes and God dispose menjadi doktrin manusia menghadapi ketidakpastian.

Konsep tawakal bisa dipahami bukan pasrah tanpa usaha melainkan menyerahkan berbagai hal yang supernatural (tak terjangkau panca indera) berkenaan dengan ketidakmampuan manusia untuk mengatasi problem hidup dan ketidakpastian fenomena yang bersinggungan dengan manusia. Dalam konsepnya, ketidakpastian (uncertainty) terjadi karena dua hal, yaitu: (1) terjadi karena fenomena alam, (2) terjadi rekayasa manusia. Antara fenomena alam dan rekayasa manusia dapat berakibat pada berbagai aspek kehidupan manusia. Isu aktual bisa dilihat seperti climate change (perubahan iklim) yang secara langsung maupun tidak langsung mengubah peta kebijakan perekonomian dunia baik lokal (dalam negeri), regional maupun internasional dan merambah semua aspek dan level ekonomi.

\section{Antara rasionalitas dan etika}

Dalam al-Qur'an makna kata yang dekat dengan etika adalah akhlak (khuluq). Untuk makna yang berkaitan dengan kebaikan Qur'an menggunakan istilah : khair (goodness), birr (righteousness), qisth (equity), 'adl (equilibrium and justice), haqq (truth and right), ma'ruf (known and approved), taqwa (piety). Sementara untuk perbuatan (action) disebutkan dengan istilah shalihat (perbuatan kebaikan) dan sayyiat (perbuatan buruk) (Beckun, 1997: 2). Seringkali, istilah "etika" dan "moral" dipergunakan secara bergaian untuk maksud yang samas. Ini bisa dipahami, karena 
sebenarnya, keduanya berasal dari dua asal kata yang berbeda, tetapi mempunyai arti yang sama. Etika berasal dari kata ethos (Yunani), sedangkan moral, asal katanya adalah moralis (Latin). Keduanya bisa diartikan sebagai kebiasaan atau adat-istiadat (custom atau mores). Tetapi kemudian etika atau etihcs, berkembang artinya menjadi sebuah bidang kajian filsafat atau ilmu pengetahuan tentang moral atau moralitas (Rahadjo, 1990: 3).

Etika mempunyai variasi makna yang bermacam-macam. Pertama, etika diartikan sebagai prinsip-prinsip aturan yang mengatur individu atau kelompok. Kedua, etics is the study of morality (etika adalah studi tentang moralitas). Terkait dengan yang kedua, moralitas (morality) didefinisikan sebagai standar perilaku yang dapat diterima oleh masyarakat sebagai perilaku yang benar atau salah, baik atau buruk (Velasquez, 1998: 8), dan setiap masyarakat mempunyai standar perilaku yang berbeda-beda. Standar moral termasuk norma (norm) yang terdapat pada perilaku yang diyakini benar atau salah, demikian juga dengan nilai (value) yang terdapat pada objek yang diyakini baik atau buruk.

Pertanyaan kemudian adalah dari mana standar moralitas itu muncul? pertama sekali standar moral seseorang berasal dari keluarga, teman, kemudian pengaruh sosial seperti media, music, sekolah, masjid dan pergaulan. Kemudian seiring dengan perkembangan kepribadian, standar moral terbentuk dan direvisi bagian-bagian yang tidak sesuai lagi melalui pengalaman, proses belajar dan pengembangan intelektual. Oleh karena itu, seseorang tidak bisa hidup dan berbuat dengan standar pribadi yang diyakini benar, tanpa mempertimbangkan standar-standar lain di luar dirinya.

Karakteristik yang membedakan perilaku sesuai dengan standar moral atau tidak, meliputi (1) standar moral terkait dengan hal yang bermanfaat atau merugikan umat manusia, (2) standar moral tidak bisa dibuat atau dirubah oleh pihak yang tidak berwenang, (3) moral standar (seharusnya) mengedepankan nilai-nilai di luar dirinya termasuk perilaku self-interest, (4) standar moral didasarkan pada pertimbangan tak berpihak, (5) moral standar diekspresikan dengan perasaan dan kosa kata (ungkapan) tertentu, misal jika berbuat salah merasa bersalah dengan penyesalan yang mendalam, kemudian diekspresikan dengan pengakuan verbal "saya khilaf" sebagai pernyataan penyesalan (Velasquez, 1998). 
Dari standar tersebut etika, kemudian mengalami perluasan makna yaitu aktivitas untuk menguji standar moral seseorang atau komunitas, mempertanyakan bagaimana standar tersebut diterapkan dalam kehidupan, apakah standar tersebut layak (reasonable) atau tidak, dan apakah standar tersebut didorong oleh alasan yang baik atau tidak. Jadi etika merupakan studi tentang moralitas karena ia merupakan proses pengujian terhadap standar moral individu atau masyarakat agar dapat menentukan apakah standar tersebut reasonable atau tidak, dan agar dapat diterapkan pada persoalan dan situasi konkrit.

Tujuan utama etika adalah (1) mengembangkan inti standar moral yang layak dijadikan pegangan, dan (2) mengembangkan standar moral yang telah dipikirkan dengan hati-hati dan telah diputuskan untuk disesuaikan dengan standar moral yang ada agar dapat diterima dan diterapkan pada pilihan hidup seseorang (Velasquez, 1998).

Etika bukan satu-satunya disiplin yang mempelajari tentang moralitas, ilmu sosial pun juga mengkajinya. Hanya saja, pendekatan yang digunakan untuk mengkaji moralitas berbeda karakteristiknya dengan etika. Etika mengkaji secara normatif, sementara ilmu sosial mengkaji secara deskriptif. Kajian normatif merupakan investigasi yang berusaha mencapai kesimpulan normatif yang mengandung tentang mana yang baik dan buruk atau tentang mana tindakan yang benar dan salah. Normatif mengandung idealitas yang seharusnya. Sedangkan kajian deskriptif secara sederhana berusaha menggambarkan atau menjelaskan dunia tanpa pencapaian kesimpulan tentang mana yang seharusnya. Seperti dalam ilmu antropologi, ilmu sosiologi, dan ilmu ekonomi mempelajari moral standar yang secara khusus dipegangi oleh wilayah atau budaya tertentu. Kajian deskriptif berusaha mengembangkan deskirpsi yang akurat dari standar moral sebuah budaya dan boleh jadi diformulasikan menjadi teori eksplanatoris tentang kerangka standar tersebut, yang tidak menentukan standar benar dan salahnya (Velasquez, 1998).

Kajian normatif dan deskriptif (positif) juga muncul pada kajian ilmu ekonomi itu sendiri. Kajian normatif berbasis pada norma dan etika, sedangkan kajian deskriptif atau positif berbasis pada realitas. Ilmu ekonomi konvensional melakukan pemisahan secara tegas antara aspek positif dan aspek normatif. Pemisahan aspek normatif dan positif mengandung implikasi 
bahwa norma berbeda dengan fakta. Dengan kata lain, realitas ekonomi merupakan sesuatu yang bersifat independen, dan karenanya bersifat obyektif dan akhirnya berlaku universal. Sehingga kecenderungannya adalah value free (bebas nilai) (Direktorat Perbankan Syariah, 2007: 19-21).

Sementara pemisahan kajian normatif dan positif pada dasarnya ditolak dalam ekonomi Islam, sebab pandangan Islam meyakini bahwa perilaku-perilaku sosial manusia tidak terjadi dengan sendirinya. Perilaku manusia bukanlah sesuatu yang bebas nilai. Manusia memiliki kecenderungan, kehendak, dan perilaku yang sangat dipengaruhi oleh nilai (value) atau etika yang diyakini, serta pandangannya terhadap kehidupan ini. Oleh karena itu, Ekonomi Islam mengedepankan pendekatan integratif antara normatif dan positif (Naqvi, 1993: 15-16).

Dalam kajian ekonomi, keterkaitan antara etika (moral) dan rasionalitas sangat dekat tetapi seringkali tidak identik menurut berbagai pandangan. Hal ini terjadi boleh jadi suatu perilaku yang dianggap rasional oleh paham konvensional dapat tidak dianggap rasional oleh pandangan Islam, demikian sebaliknya. Tindakan etis oleh pandangan konvensional seringkali diartikan sebagai pengorbanan kepentingan individu atau material untuk mengedepankan kepentingan sosial atau non material. Sehingga, ketika perilaku rasional ekonomi diartikan sebagai upaya untuk mewujudkan maslahah materi semata, maka perilaku etis dipandang sebagai perilaku yang tidak rasional dan karenanya dikeluarkan dari pokok bahasan ilmu ekonomi.

Dalam ekonomi Islam, rasionalitas mempunyai batasan-batasan tertentu, karena rasionalitas yang berbasis akal harus dikendalikan oleh etika dan norma yang digali dari ajaran Islam yang berasal dari sumber otoritatif yaitu Qur'an dan Hadis. Etika bukan hanya berlaku sebagai border (pembatas), tetapi ia secara internal dan inheren berlaku pada setiap muslim dalam berperilaku ekonomi. Oleh karena itu, rasionalitas dalam ekonomi Islam berorientasi pada subyek yakni perilaku muslim dalam ekonomi. Sehingga pandangan rasionalitas dalam ekonomi Islam berimplikasi pada dihadapkannya rasionalitas yang berbasis ajaran Islam dengan pemahaman rasionalitas yang selama ini berkembang pada perekonomian modern (konvensional). Implikasi Rasionalitas (Agil, 1992: 38) tersebut antara lain: pertama, Humanity-bounded rationality vs egoistic rationality. Merubah 
wajah rasionalitas egois menjadi rasional yang berpihak pada kemanusiaan, kedua, Altruism vs egoism. Merubah pandangan atau paham mementingkan diri sendiri un sich menjadi peka dan peduli terhadap orang lain dan lingkungan sekitarnya, dan ketiga, Social considerations vs individualistic. Sifat dan perilaku individualis dirubah menjadi selalu mempertimbangkan kehidupan sosial. Ketiga pola rasionalitas tersebut, yaitu Humanity-bounded rationality, Altruism dan Social considerations, bertitik tolak pada subyek atau manusia sebagai pelaku. Sementara ketiga rasionalitas yang bertolak belakang bertitik tolak pada objek atau materi. Ada nilai etis yang terlupakan yaitu edukasi pelaku ekonomi sebagai tanggung jawab manusia muslim di dunia, yang ini tidak muncul pada ekonomi konvensional.

\section{Rasionalitas dalam Ekonomi}

Sebelum menjelaskan tentang makna rasionalitas, seringkali para ekonom mencari kejelasan ungkapan umum dalam ilmu ekonomi bahwa "keputusan yang diambil oleh pelaku ekonomi harus rasional". Ungkapan tersebut mengarah pada substansi bahwa pelaku ekonomi akan membuat keputusan dengan akal sehat (rasional) atas dorongan kepentingan pribadinya untuk mensejahterakan dirinya. Namun persoalannya adalah rasionalitas sendiri mengandung muatan dan ukuran makna yang berbeda di dalam masyarakat. Boleh jadi rasional menurut seseorang, tetapi tidak rasional menurut yang lain. Demikian juga individu dari sebuah masyarakat mempunyai pandangan rasionalitas yang berbeda dengan individu yang lain. Hal ini terjadi akibat dari perbedaan keyakinan dan pengaruh budaya yang berlaku di masyarakat (Agil, 1992: 31).

Dalam bidang keilmuan pun terjadi perbedaan pandangan. Khususnya, ilmu sosial memandang bahwa secara umum rasionalitas menjadi kajian yang kontroversial dan tidak ada makna definitif yang bisa diterima oleh semua kalangan. Apa yang oleh ahli ekonomi dan statistik dianggap sebagai rational decision process, oleh ahli psikologi dianggap sebagai habitual behaviour. Apa yang dianggap oleh ahli psikologi sebagai rational choice, oleh ahli ekonomi dan statistik tidak sama sekali dianggap rasional. Konsep rasionalitas dalam ekonomi sering memunculkan istilah rational economic man, yang dalam ekonomi konvensional menyamakan rasionalitas tersebut 
dengan serving of self-interest through the maximization of wealth and want satisfaction. Kendali self-interest didasarkan hanya pada the moral equivalent of the force of gravity in nature (Myers, 1983: 4).

Rasionalitas sangat dekat dengan self-interest, sehingga oleh Robert H. Frank dikategorikan menjadi 2 macam, yaitu : (1) self-interest rationality (rasionalitas kepentingan pribadi), ini jenis genuine rationality dan (2) presentaim rationality (rasionalitas tujuan yang dihadapi berdasarkan preferensi), ini muncul dari self-interest yang dipengaruhi oleh faktor internal (psikologis) maupun eksternal (sosiologis, lingkungan) secara ekonomi (Karim, 2007: 51-52). Menurut Walter Nicholson (dalam Karim, 2007) self-interest didasarkan pada 3 sifat manusia yang menjadi aksioma kecenderungan manusia, yaitu: (1) completeness (kelengkapan), maknanya pada situasi yang sama manusia tidak dapat mempunyai pilihan yang jelas karena keduanya menjadi prioritas dan diperlukan, (2) transitivity (transitivitas), maknanya ada prioritas pilihan, dan (3) contiunuity (kontinuitas), maknanya berbagai hal (media, situasi, dan lain-lain) yang dibutuhkan untuk menunjang tercapainya tujuan harus pula menjadi prioritas pilihan. Kecenderungan itu menggiring manusia secara natural dan naluriah membangun preferensinya. R. Varian (dalam Karim, 2007) membuat tiga asumsi tentang preferensi, yaitu: (1) strong monotonicity (kemonotonan yang kuat), maknanya kecenderungan manusia adalah ingin lebih banyak atau lebih baik dan tetap pada posisi semula adalah batas minimal, (2) local non-satiation (diri yang tidak pernah merasa puas), maknanya perubahan harus selalu tercapai meskipun sedikit, dan (3) strict convexity (konveksitas -cembung- ketat), maknanya manusia hakikatnya suka yang rata-rata ketimbang yang ekstrim (Karim, 2007).

Setelah melihat kecenderungan self-interest terhadap rasionalitas, kemudian secara teoritis, terminologi rasionalitas dibangun atas dasar asumsi. Oleh Roger LeRoy Miller (Karim, 2007: 51-59), asumsi rasionalitas adalah manusia berperilaku secara rasional (masuk akal), dan tidak akan secara sengaja membuat keputusan yang akan menjadikan mereka lebih buruk. Rasional tersebut membentuk sebuah perilaku yang mengerucut pada dua makna yaitu, (1) metode, yang maknanya adalah tindakan yang dipilih berdasarkan pikiran yang beralasan, bukan berdasarkan kebiasaan, prasangka atau emosi; dan (2) hasil, yang maknanya tindakan yang benar-benar dapat mencapai tujuan yang ingin dicapai). 
Asumsi-asumsi tersebut dibangun atas dasar kaidah-kaidah yang diterima secara universal dan tidak perlu dilakukan pengujian untuk membuktikan kebenarannya, yang disebut sebagai aksioma. Aksioma-aksioma ini diposisikan sebagai acuan dalam pengujian rasionalitas dari suatu argumen atau perilaku. Dalam banyak hal, aksioma didasarkan pada budaya yang bersifat universal, namun penafsiran operasional dari nilai budaya tersebut didasarkan pada cara pandang dan berpikir yang ada pada budaya tersebut yang sering dipengaruhi oleh situasi dan kondisi yang melingkupinya (Direktorat Perbankan Syariah, 2007: 19-21).

Menurut Edgeworth dalam Mathematical Psychics, "prinsip ekonomi menyatakan bahwa setiap agen digerakkan hanya oleh kepentingan pribadi (self-interest)". Asumsi universal mengatakan bahwa produsen berekspresi dengan maksimisasi keuntungan baik dengan maksimisasi output atau minimisasi biaya. Sedangkan konsumen berekspresi dengan maksimisasi kepuasan (utility). Dalam analisis ekonomi Islam ekonomi, ekspresi yang digerakkan hanya oleh self-interest demi maksimisasi ini yang disebut rasionalitas egois (egoistic rationality) (Agil, 1992: 32).

Rasionalitas egois dapat dilihat kelemahannya dari lima sudut pandang. Pertama, kasus ekonomi selalu diliputi dengan ketidakpastian (uncertainty), sehingga rasionalitas egois hanya memandang ekonomi sebagai fenomena yang ideal dan pasti, namun justru itu yang dinilai tidak realistis. Kedua, ekonomi yang digerakkan oleh sifat egois pasti tidak akan menyentuh wilayah sosial, ironisnya adalah bahwa dirinya merupakan bagian dari sistem sosial yang tergantung pula pada komunitas yang lain. Ketiga, sifat egois, menurut analisis model perilaku manusia dan diakui oleh para ekonom, bukan representasi dari sifat manusia dan memang tidak realistis. Keempat, rasional yang dimaksud dalam ekonomi meliputi maksimisasi dan konsistensi pilihan. Menilai yang terakhir dari sudut egois, manusia cenderung tidak konsisten dari segi isi (content), namun hanya pilihan general yang sering disebut want (keinginan) yang tak terbatas dan cenderung pengejaran objek, bukan need (kebutuhan) yang cenderung terbatas dan bersifat subyekif. Kelima, sifat egois kodratinya cenderung mendorong materialistis, yang itu sejatinya dibatasi oleh hukum, peraturan, tradisi, nilai-nilai agama dan moral, serta tanggung jawab sosial. 
Namun tidak bisa dipungkiri, sejarah mencatat bahwa adagium "manusia rasional dalam ekonomi digerakkan oleh kepentingan pribadi" berasal dari proses sejarah yang memisahkan antara kekuasaan ekonomi dan agama (gereja) ketika itu. Masa itu dikuasai Kaum Merchantilism periode awal yang melakukan monopoli dan kekuasaan gereja melarang memperkaya diri dengan kekayaan. Namun, pada akhir abad 17, lambat laun perubahan radikal muncul pada masyarakat asketis karena pengaruh neo-klasik yang menghidupkan kembali paham kapitalisme dan mendapat dukungan prinsip etika protestan yang membenarkan motif self-interest (Agil, 1992: 33).

Pengaruh kepentingan pribadi dan dukungan kaum agamawan menjadi jastifikasi untuk memperkaya diri sendiri dan mengabaikan kepentingan sosial. Kenyataan yang kaya terus memperkaya diri dan yang miskin semakin diekploitasi dan dibuai mimpi terus merambah semua lini perekonomian. Alih-alih berbicara kesejahteraan masyarakat, yang menjadi target ekonominya adalah monopoli gaya baru.

Jika dalam ekonomi konvensional, manusia disebut rasional secara ekonomi jika mereka selalu memaksimumkan utility untuk konsumen dan keuntungan untuk produsen. Maka dalam ekonomi Islam seorang pelaku ekonomi, produsen atau konsumen, akan berusaha untuk memaksimalkan maslahah (Direktorat Perbankan Syariah, 2007: 19-21). Konsep rational economic man dalam ekonomi Islam juga tidak dibatasi untuk kepentingan pribadi di dunia semata, tetapi juga diperluas jangkauannya untuk kepentingan Akhirat melalui kerelaan seorang mukmin terhadap nilai-nilai moral yang dapat mengendalikan self-interest untuk mempertimbangkan social-interest (Chapra, 2005).

Beberapa pakar ekonomi Islam membuat batasan terhadap rasionalitas dalam ekonomi Islam. Kahf (1978: 10) memberikan catatan bahwa:

The time horizon of an Islamic individual is extended to include the hereafter which implies that he should not limit his behaviour to doing things which he can collect the benefits resulting from them in this life, he so oriented that he will do what is good or useful for its sake. 
Ia juga menambahkan bahwa Islamic Rationality yang dimaksud olehnya adalah validity of the maximisation proposition in the context of consumer behaviour in Islam. Menurutnya, syarat maksimisasi adalah konsistensi terhadap nilai-nilai dalam perilaku ekonomi (Kahf, 1978: 10).

Siddiqi (1972: 89) terkonsentrasi pada bidang konsumsi menyatakan bahwa hal pertama yang harus disadari konsumen adalah bahwa dirinya sekarang hidup sebagai muslim tentunya standar hidup yang digunakan adalah standar Islam. Salah satunya bahwa untuk mencapai kepuasan, konsumen tidak lagi hanya mengejar maksimisasi kepuasan semata secara ekonomi. Inilah yang olehnya disebut sebagai Islamic rationality.

Dalam konteks rasionalitas dalam konsumsi yang lebih spesifik, Fahim Khan (adlam Agil, 1992: 1973) membedakan antara maslahah dan kepuasan(utility). Maslahah dikoneksikan dengan kebutuhan (needs), sedangkan kepuasan (utility) dikoneksikan dengan keinginan (wants). Ia menderivasikan pandangan pada konsep maqashid shariah dengan maslahah yang berujung pada li mashalih al-'ibad (untuk kemaslahatan manusia).

Berkaitan dengan rasionalitas perilaku muslim dalam hal kepuasan (utility), Zarqa (1992: 105-109) membedakan secara fundamental antara homo economicus dan homo Islamicus, di mana fungsi-fungsi yang melekat dengan homo economicus melekat juga pada homo Islamicus, yang membedakan adalah adanya pahala (reward) dan hukuman -dosa- (punishment) di akhirat.

Pengembangan rasionalitas (Agil, 1992: 38): pertama, rasionalitas terbatas (bounded rationality). Pernyataan bahwa setiap agen ekonomi memiliki pengetahuan dan informasi yang lengkap untuk membuat keputusan adalah tidak realistis. Oleh karena itu, kebutuhan akan keterbatasan tersebut menjadi niscaya. Rasionalitas manusia adalah rasionalitas yang terbatas, ternyata berkaitan dengan keputusan ekonominya manusia bergantung pada teknologi. Kedua, altruisme, diartikan sebagai kepekaan terhadap sesama. Kata altruism (berasal dari bahasa Perancis autre yang bermakna other (yang lain), ia juga berasal dari bahasa Latin alter bermakna other (yang lain) dicetuskan pertama kali oleh Auguste Comte, Perancis, pendiri aliran Positivism, untuk menggambarkan doktrin etikanya. Ia percaya bahwa individu mempunyai kewajiban moral untuk layani kepentingan orang lain atau greet good 
of humanity. Sebagai nama doktrin etika, altruisme, ketentuan dokrin etika yang dijalankan merujuk pada ajaran tersebut yaitu altruisme (melayani orang lain menempatkan kepentingan mereka diatas kepentingan sendiri. Manusia rasional bukan berarti manusia tanpa perasaan dan emosi, tetapi manusia yang peka terhadap sekitar dan problem umat manusia. Upaya yang dilakukan adalah menggabungkan rasionalitas egois dan rasional altruis, yang posisinya sebagai alat maksimisasi kepuasan, dengan stimulan bahwa (1) perilaku memberi (philanthropy acts) menciptakan kepuasan, dan (2) pencitraan image kepada publik. Ketiga, pandangan dunia Islam (Islamic world-view).

Secara konseptual dan teoritis, rasionalitas dalam ekonomi Islam dibangun atas dasar aksioma yang diderivasi dari nilai dan ajaran Islam yang merupakan kaidah yang bersifat umun dan berlaku universal. Aksioma tersebut antara lain (Direktorat Perbankan Syariah, 2007: 19-21): Pertama, Setiap pelaku ekonomi bertujuan untuk mendapatkan maslahah. Maslahah adalah segala bentuk keadaan ataupun perilaku yang mampu meningkatkan kedudukan manusia sebagai makhluk yang paling mulia. Sebaliknya, suatu keadaan yang maslahatnya negatif disebut masharat. Maslahat sangat erat kaitannya dengan maqashid syariah yang mengandung lima tujuan utama, (1) maslahat agama, (2) maslahat jiwa, (3) maslahat akal, (4) maslahat keturunan, dan (5) maslahat kekayaan, Secara alami maslahah mengandung makna (1) maslahah yang banyak lebih disukai dari pada yang lebih sedikit, termasuk di dalamnya adalah monotonicity (monoton), dan (2) Maslahah diupayakan terus meningkat sepanjang waktu, dimaknai dari quasiconcavity, di mana situasi yang menunjukkan non-decreasing. Kedua, setiap pelaku ekonomi selalu berusaha untuk tidak melakukan kemubadziran (nonwasting). Ketiga, setiap pelaku ekonomi akan berhubungan dengan resiko, yang mengandung 3 tindakan, yaitu (1) selalu berusaha untuk meminimumkan resiko, (2) berhadapan dengan resiko ketidakpastian, dan (3) melengkapi informasi dalalm upaya meminimumkan resiko.

Aksioma yang bersifat universal tersebut, didukung oleh aksioma yang hanya dikandung dalam ajaran Islam dan hanya diyakini oleh seorang muslim, yaitu (1) adanya kehidupan setelah kematian di dunia, (2) kehidupan dunia merupakan media untuk mencapai kehidupan akhirat, dan (3) sumber utama hanyalah Qur'an dan Hadis. 


\section{Penut up}

Dari paparan pembahasan pada sub topik disimpulkan sebagai berikut:

1. Rasionalitas dalam ekonomi sering diartikan sebagai self-interest, yang menggerakkan pelaku ekonomi untuk melakukan hal yang diinginkan dan dibutuhkan.

2. Ada beberapa perbedaan tentang rasionalitas dalam ekonomi konvensional dan ekonomi Islam. Perbedaan mendasar adalah sumber pengambilan sebagai dasar filosofinya dan rentang waktu yang melingkupinya.

3. Etika dan rasionalitas saling berhubungan dan saling mempengaruhi satu dengan yang lain. Namun, sering kali keduanya mempunyai persepsi standar yang berbeda bila terkait dengan standar budaya masyarakat tertentu.

4. Adanya karakteristik trandensi dalam ekonomi Islam yang tidak dimiliki oleh ekonomi konvensional, yaitu pasrah kepada resiko ketidakpastian sebagai ekspresi tawakal dan jangkauang waktu yang tak terbatas (time horizon) dari kehidupan dunia sampai kehidupan akhirat.

5. Rasionalitas dalam ekonomi Islam sangat dipengaruhi oleh eksternalitas yang mendorong untuk berbuat baik kepada sesama sesuai dengan kodrat manusia. Altruisme, humanity-bounded rationality dan social considerations merupakan rasionalitas yang dikembangkan ekonomi Islam yang didasarkan pada sumber otoritatif.

\section{Daftar Pustaka}

Al-Zarqa, Muhammad Anas. "A Partial Relationship in a Muslim's Utility Function", dalam Sayyid Tahir, Aidit Ghazali, Syed Omar Syed Agil, Readings in Microeconomics : An Islamic Perspective, Malaysia: Longman Malaysia, 1992

Chapra, M. "Islamic Economics: What It Is and How It Developed". EH.Net Encyclopedia, edited by Robert Whaples. October 14, 2005. URL http://eh.net/encyclopedia/article/chapra.islamic

Direktorat Perbankan Syariah \& Pusat Pengkajian dan Pengembangan Ekonomi Islam, 2007. Text Book Ekonomi Islam, Jakarta : BI \& P3EI-UII. 
http://en.wikipedia.org/wiki/Altruism.

http://en.wikipedia.org/wiki/Rationality

Kahf, Monzer. 1978. The Islamic Economics, Indiana: The MSA.

Karim, Adiwarman A. 2007. Ekonomi Mikro Islami, Jakarta : Rajawali Press.

Keraf, A. Sony. 1996. Pasar Bebas, Keadilan dan Peran Pemerintah: Telaah atas Etika Politik Ekonomi Adam Smith, Yogyakarta : Kanisius.

Khan, Fahim. "Theory of Consumer Behaviiour in an Islamic Perspective", dalam Sayyid Tahir, Aidit Ghazali, Syed Omar Syed Agil, Readings in Microeconomics : An Islamic Perspective, Malaysia: Longman Malaysia, 1992.

Myers, Milton L., 1983. The Soul of Modern Economic Man: Ideas of SelfInterest, Thomas Hobbes to Adam Smith, Chicago: University of Chicago Press.

Rafik Issa Beckun, Islamic Business Ethics, Virginia-USA: IIIT, 1997.

Rahadjo, M. Dawam. 1990. Etika Ekonomi dan Manajemen, Yogyakarta : Tiara Wacana.

Raliby, Osman. 1982. Kamus International, Jakarta : Bulan Bintang.

Salim, Peter, 2000. Salim's Ninth Collegiate English-Indonesian Dictionary, Jakarta : Modern English Press.

Siddiqi, Muhammad Nejatullah. 1972. Economic Enterprise in Islam, Lahore : Islamic Publication.

Syed Nawab Haider Naqvi, Islam, Economics, and Society, London : Kegan Paul International, 1993.

Syed Omar Syed Agil, "Rationality in Economic Theory : A Critical Appraisal", dalam Sayyid Tahir, Aidit Ghazali, Syed Omar Syed Agil, Readings in Microeconomics : An Islamic Perspective, Malaysia: Longman Malaysia, 1992.

The English Language Institute of America, Inc., The New Grolier Webster International Dictionary of the English Language, New York : Grolier Incorporated, 1972, Volume II

Velasquez, Manuel G. 1998. Business Ethics: Concepts and Cases, New Jersey: Prentice-Hall International Inc, International Edition.

Yayasan Dana Buku Franklin Jakarta, Ensiklopedi Umum, Yogyakarta : Kanisius, 1973. 